\title{
KEMAMPUAN GURU MATEMATIKA DALAM MERENCANAKAN DAN MELAKSANAKAN PEMBELAJARAN DI SMA NEGERI 3 PALU
}

\author{
Herdawati $^{1)}$, Sutji Rochaminah ${ }^{2)}$, Baharuddin Paloloang ${ }^{3)}$ \\ herdacapcent@gmail.com ${ }^{1)}$, suci_palu@yahoo.co.id ${ }^{2)}$, baharuddinpaloloang@gmail.com ${ }^{3)}$
}

\begin{abstract}
Abstrak: Tujuan penelitian ini adalah untuk memperoleh deskripsi kemampuan guru matematika dalam merencanakan dan melaksanakan pembelajaran di SMA Negeri 3 Palu. Jenis penelitian yang digunakan adalah penelitian kualitatif. Untuk memperoleh data penelitian digunakan tiga teknik pengumpulan data yaitu rekaman video, wawancara, dan dokumentasi. Hasil penelitian menunjukan perencanaan pelaksanaan pembelajaran sudah sesuai dengan pedoman pembuatan RPP yang di keluarkan oleh Kementrian Pendidikan dan Kebudayaan tentang Pembelajaran pada Pendidikan Dasar dan Menengah yang di dalamnya terdapat komponen RPP yaitu identitas sekolah, identitas mata pelajaran, kelas/semester, materi pokok, alokasi waktu, KD, indikator, tujuan pembelajaran, metode, kegiatan pembelajaran, media, sumber, dan penilaian, sedangkan pada pelaksanaan pembelajaran yang dilaksanakan oleh kedua guru matematika yang menjadi subjek penelitian yaitu terdiri dari pendahuluan, inti, dan penutup.
\end{abstract}

Kata kunci: Kemampuan guru, merencanakan, melaksanakan pembelajaran

\begin{abstract}
The purpose of this study is to obtain a description of the ability of mathematics teachers in planning and implementing learning in SMA Negeri 3 Palu. The type of research used is qualitative research. To obtain research data used three techniques of data collection ie video recording, interviews, and documentation. The result of the research shows that the planning of learning implementation is in accordance with the guidance of making RPP which is issued by the Ministry of Education and Culture of Learning on Primary and Secondary Education in which there are RPP components namely school identity, subject identity, class / semester, subject matter, , KD, indicators, learning objectives, methods, learning activities, media, sources, and assessments. While on the implementation of learning conducted by both teachers of mathematics who became the subject of research that consists of the introduction, core, and cover.
\end{abstract}

Key words: Teacher ability, planning, implementing learning

Pendidikan adalah suatu proses yang dapat mengubah pengetahuan serta dapat mengembangkan kualitas setiap diri manusia dari waktu ke waktu dengan cara melalui suatu proses pembelajaran, pelatihan, dan penelitian. Oleh sebab itu, pendidikan mempunyai peranan yang sangat penting bagi kehidupan manusia. Pendidikan dapat dikatakan berhasil jika pendidikan itu mampu menghasilkan sumber daya manusia (SDM) yang handal. Maka dari itu, keberhasilan dunia pendidikan sangat dipengaruhi oleh beberapa komponen diantaranya sarana dan prasarana, lingkungan belajar yang efektif, media pembelajaran, dan lebih penting adalah peran guru dalam merencanakan dan melaksanakan suatu proses pembelajaran. Guru dianggap komponen yang penting karena mampu memahami, mendalami, melaksanakan, dan akhirnya dapat mencapai suatu tujuan pendidikan (Nurdin, 2010:17).

Pada hakikatnya bila suatu kegiatan direncanakan lebih dahulu maka tujuan dari kegiatan tersebut akan lebih terarah dan lebih berhasil. Itulah sebabnya seorang guru harus memiliki kemampuan dalam merencanakan pengajaran. Perencanaan berasal dari kata rencana dan berarti pengambilan keputusan tentang hal yang harus dilakukan untuk 
mencapai tujuan tertentu. Hal ini sesuai dengan yang dikemukakan oleh Agung (2013:1) bahwa perencanaan adalah proses untuk mencapai tujuan yang harus dimulai dari penetapan tujuan yang akan dicapai melalui analisis kebutuhan, kemudian menentukan langkah-langkah yang harus dilakukan untuk mencapai tujuan pengajaran. Pengajaran merupakan suatu rangkaian peristiwa yang direncanakan untuk disampaikan, untuk menggiatkan dan mendorong belajar siswa yang merupakan proses merangkai situasi belajar (yang terdiri dari ruang kelas, siswa dan materi kurikulum) agar belajar menjadi lebih mudah. Perencanaan juga dapat bermanfaat bagi guru sebagai kontrol terhadap diri sendiri agar dapat memperbaiki cara pengajarannya. Setelah guru merencanakan proses pembelajaran maka tugas guru selanjutnya adalah melaksanakan pembelajaran yang didalamnya terjadi interaksi antara guru dan siswa agar proses pembelajaran berjalan dengan lancar. Pendapat tersebut sesuai yang dikemukakan oleh Marno (2009:29) bahwa melaksanakan pembelajaran adalah interaksi guru dengan siswa dalam rangka menyampaikan bahan pelajaran kepada siswa dan untuk mencapai tujuan pengajaran. Selain itu, untuk menjadi guru yang handal, guru harus memiliki kreativitas yang tinggi dalam merencanakan dan melaksanakan pembelajaran sehingga proses pembelajaran dapat berjalan dengan efektif dan mampu mencapai tujuan pendidikan yang berkualitas. Salah satu guru yang harus memiliki kreativitas yang tinggi adalah guru matematika, karena matematika adalah pelajaran yang membutuhkan tingkat ketelitian dan pemahaman yang mendalam.

Menciptakan pembelajaran yang efektif memang memerlukan usaha dan tindakan yang konsisten dan kontinu untuk mewujudkannya di dalam kelas. Oleh sebab itu, guru perlu mempersiapkan hal-hal yang menyangkut pembelajaran yang akan diajarkan di dalam kelas sebelum pembelajaran dimulai. Kegigihan melakukan eksperimen mengajar menjadi kunci sukses dalam menemukan cara mengajar yang efektif. Agar dapat mengajar dengan efektif, guru harus meningkatkan mutu belajar siswa dan meningkatkan mutu mengajarnya. Agar dapat meningkatkan mutu belajar siswa, guru harus membuat siswa aktif dalam melakukan pembelajaran dan guru perlu menunjukkan keseriusannya dalam mengajar agar dapat membangkitkan minat dan motivasi siswa dalam belajar.

SMA Negeri 3 Palu merupakan sekolah menengah atas yang telah banyak meluluskan siswa dan siswi, serta menghasilkan alumni-alumni yang sukses dalam berbagai bidang pekerjaan. Tentunya dalam mencapai kesuksesan tersebut tidak terlepas dari peran-peran guru yang mengajar di sekolah SMA Negeri 3 Palu yang telah mentransfer ilmu dan pengetahuannya kepada pesera didiknya. Berdasarkan uraian tersebut maka peneliti tertarik mendeskripsikan kemampuan guru matematika dalam merencanakan dan melaksanakan pembelajaran di SMA Negeri 3 Palu. Rumusan masalah dalam penelitian ini adalah bagaimana kemampuan guru matematika dalam merencanakan dan melaksanakan Pembelajaran di SMA Negeri 3 Palu?

\section{METODE PENELITIAN}

Jenis penelitian ini adalah penelitian kualitatif. Subjek penelitian ini adalah guru matematika di SMA Negeri 3 Palu. Data diambil dengan menggunakan rekaman video, wawancara, dan dokumentasi. Instrumen penelitian terdiri atas pedoman wawancara dan beberapa alat elektronik, yaitu Handphone (HP) yang digunakan untuk merekam percakapan peneliti dengan guru, dan kamera digital yang digunakan untuk merekam aktivitas guru dan siswa saat pembelajaran berlangsung. 
Analisis data kemampuan guru matematika dalam merencanakan dan melaksanakan pembelajaran di SMA Negeri 3 Palu mengacu pada analisis data kualitatif model Miles dan Huberman (1992) yakni, reduksi data, penyajian data, dan penarikan kesimpulan.

\section{HASIL PENELITIAN}

Berdasarkan hasil dokumentasi bahwa RPP (Rencana Pelaksanaan Pembelajaran) yang dimiliki oleh guru tersebut sesuai dengan pedoman dalam penyusunan RPP, karena dalam RPP tersebut terdapat komponen-komponen dan sistematika RPP yang dikeluarkan oleh Kementrian Pendidikan dan Kebudayaan Direktorat Jenderal Pendidikan Dasar dan Menengah yang meliputi identitas sekolah, identitas mata pelajaran, materi pokok, alokasi waktu, kompetensi dasar, indikator, tujuan pembelajaran, materi pembelajaran, metode atau model pembelajaran, kegiatan pembelajaran, media atau sumber belajar, dan penilaian.

Proses belajar mengajar pada penelitian ini terdiri atas tiga kegiatan yaitu kegiatan pendahuluan, inti, dan penutup. Pada kegiatan pendahuluan, guru terlebih dahulu mempersiapkan siswa untuk belajar dan membuka pembelajaran dengan mengucapkan salam dan mengecek kehadiran siswa. Selanjutnya, guru memberikan apersepsi kepada siswa dan menyampaikan kepada siswa materi yang akan dipelajari yaitu untuk menentukan nilai limit fungsi aljabar dengan cara membacakannya pada power point (KG01) yang sudah dipersiapkan oleh guru tersebut. Setelah itu, guru menyampaikan kompetensi dasar yang akan dicapai kepada siswanya. Setelah menyampaikan kompetensi dasar, guru tersebut memberikan motivasi kepada siswanya dengan cara bertanya kepada siswa tentang penyelesaian soal yang dipaparkanya melalui power point (KG02).

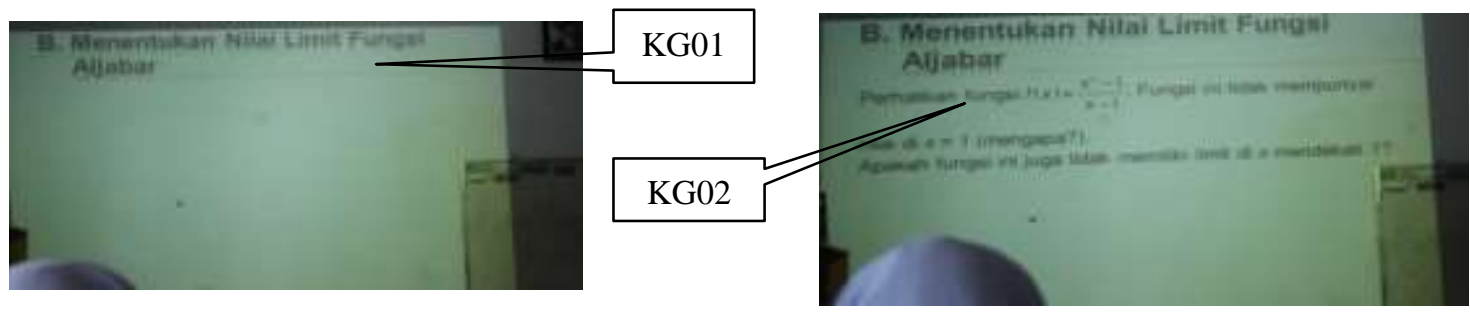

Gambar 1. Materi yang dipelajari

Gambar 2. Guru memaparkan soal

Kegiatan inti, (1) guru menanyakan siswa 3 cara dalam menyelesaikan limit fungsi aljabar sambil berdiri di depan siswa dan mengarahkan siswa untuk menjawabnya (KG03). Kemudian siswa-siwa tersebut menjawab pertanyaan gurunya dengan mengucapkan 3 cara dalam menyelesaikan limit fungsi " subtitusi, pemfaktoran, dan dikalikan akar sekawan" (KS01). (2) Guru menjelaskan cara penyelesaian limit fungsi aljabar menggunakan ke 3 cara. Pada penjelasan pertama, guru terlebih dahulu menjelaskan penyelesaian limit fungsi aljabar menggunakan cara subtitusi dan pemfaktoran dengan memberikan contoh soal kepada siswa dan meminta salah satu siswa untuk mengerjakannya di papan tulis. Ketika siswa tersebut mengerjakan soal dengan cara subtitusi hasilnya tak tentu kemudian guru tersebut memberitahukan kepada siswanya jika dengan cara subtitusi hasilnya tak tentu, maka harus menggunakan cara lain yaitu cara pemfaktoran, kemudian siswa mengerjakan soal menggunakan cara pemfaktoran (KS02). 


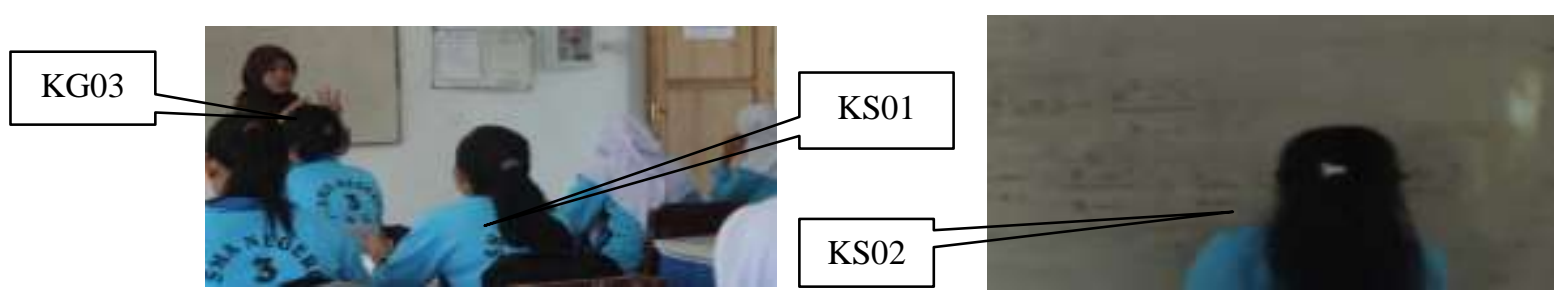

Gambar 3. Guru bertanya kepada siswa

Gambar 4. siswa menjawab contoh soal

Selanjutnya (3) Guru melihat pekerjaan siswanya dan bertanya kepada siswa yang lain tentang hasil dari perkerjaan temannya apakah sudah betul atau belum. Kemudian siswa-siswanya menjawab "sudah betul". Setelah itu, guru lanjut menjelaskan materi menggunakan cara dikalikan akar sekawan dengan melakukan hal yang sama. (4) Setelah selesai menjelaskan tentang materi limit fungsi aljabar maka guru tersebut membagi siswanya kedalam beberapa kelompok yaitu 6 kelompok (KG04). Siswa mulai mencari teman kelompoknya, satu kelompok terdiri dari 6 orang (KS03). (2) Kemudian guru membagikan LKS kepada setiap kelompok untuk dikerjakan. (3) Sebelum mengerjakan soal yang terdapat pada LKS yang sudah dibagikan, guru membacakan petunjuk dalam mengerjakan soal pada lembar LKS (KG05) dan siswa memperhatikan petunjuk yang terdapat pada LKS (KS04). (4) Guru meminta siswanya untuk mengerjakan soal yang terdapat pada LKS dengan waktu 15 menit, dan meminta siswanya untuk berbagi soal bersama teman kelompoknya agar bisa diselesaikan dengan cepat. (5) Guru berjalan-jalan sambil memantau siswa dalam bekerja dan ketika siswa mengalami kesulitan guru menjadi narasumber atau fasilitator dalam menjawab pertanyaan ketika siswa mengalami kesulitan (KG06). Setelah siswa selesai, (6) guru meminta perwakilan setiap kelompok untuk memaparkan hasil jawaban mereka ke papan tulis), kemudian perwakilan tiap-tiap kelompok maju ke depan untuk memaparkan jawaban mereka di papan tulis (KS05) dan siswa-siswa yang lain memperhatikan temanya yang berada di depan. (7) Guru memperhatikan jawaban siswa. (8) Kemudian guru bertanya kepada siswa " bagaimana hasil pekerjaan temanmu yang nomor 1 sudah benar?" siswa menjawab "sudah". Ketika jawabannya sudah benar, (9) selanjutnya guru memperhatikan jawaban nomor 2 dan bertanya lagi kepada siswa " sudah benar?" kemudian para siswa menjawab "sudah, bu" setelah itu guru tersebut menyampaikan bahwa dalam penyelesaian soal nomor 2 bisa menggunakan cara lain yaitu dengan cara dikalikan akar sekawan. (10) Guru meminta siswa-siswanya untuk mencatat hasil jawaban temannya yang ada di papan tulis, dan ketika jawaban semua benar, guru meminta siswa lainya untuk memberikan reward kepada kelompok yang sudah menjawab benar dengan cara memberikan tepuk tangan. Setelah selesai, guru mengarahkan siswa-siswanya untuk kembali ke tempat duduknya semula.

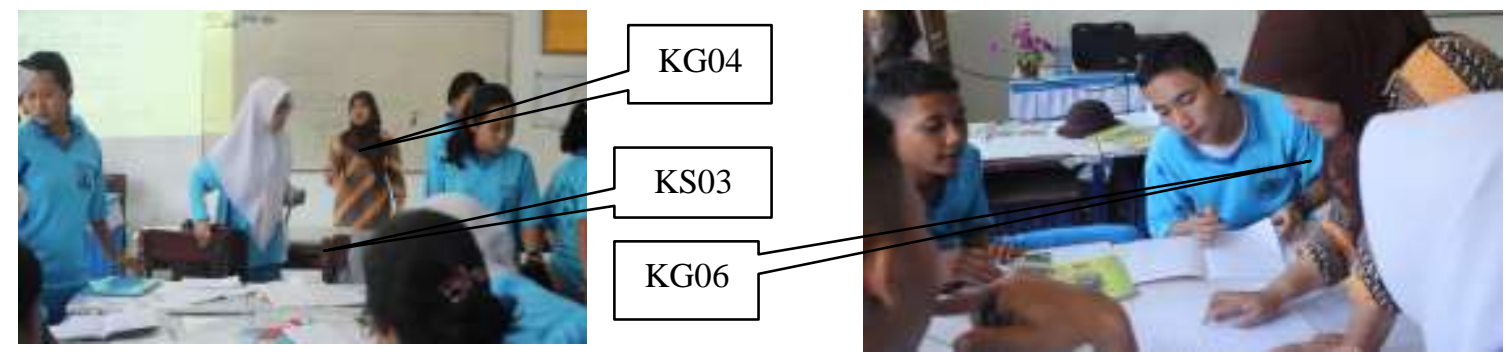

Gambar 5. Guru membagi kelompok belajar

Gambar 7. Guru menjelaskan soal 


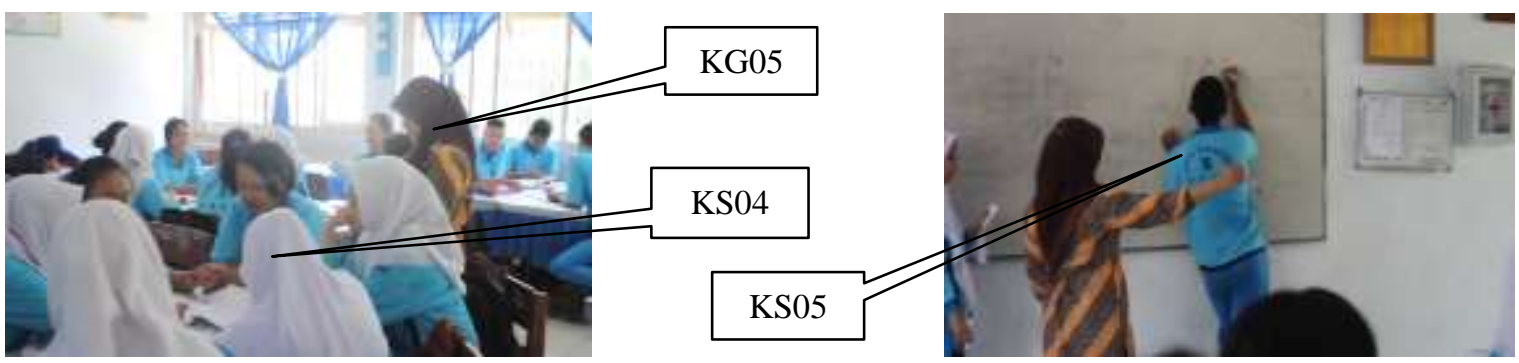

Gambar 6. Guru membaca petunjuk dalam menyelesaikan soal

Gambar 8. Guru memberikan spidol dan siswa mengerjakan soal

Kegiatan penutup pada akhir pertemuan, (1) guru mengajak dan membimbing siswa untuk menyimpulkan hasil pembelajaran, dan memberikan kesempatan kepada siswa untuk memberikan kesimpulan dari hasil pembelajaran (KS06) dan (KS07). (2) Guru memberikan koreksi dan penguatan atas hasil kesimpulan siswa (KG07). (3) Guru memberikan arahan kepada siswa agar siswa tetap giat belajar dan jangan mudah putus asa dalam belajar. (4) Guru memberikan PR kepada siswanya dengan meminta siswanya untuk melihat soal yang terdapat pada buku paket dan akan diperiksa minggu depan. (5) Pembelajaran ditutup dengan mengucapkan salam.
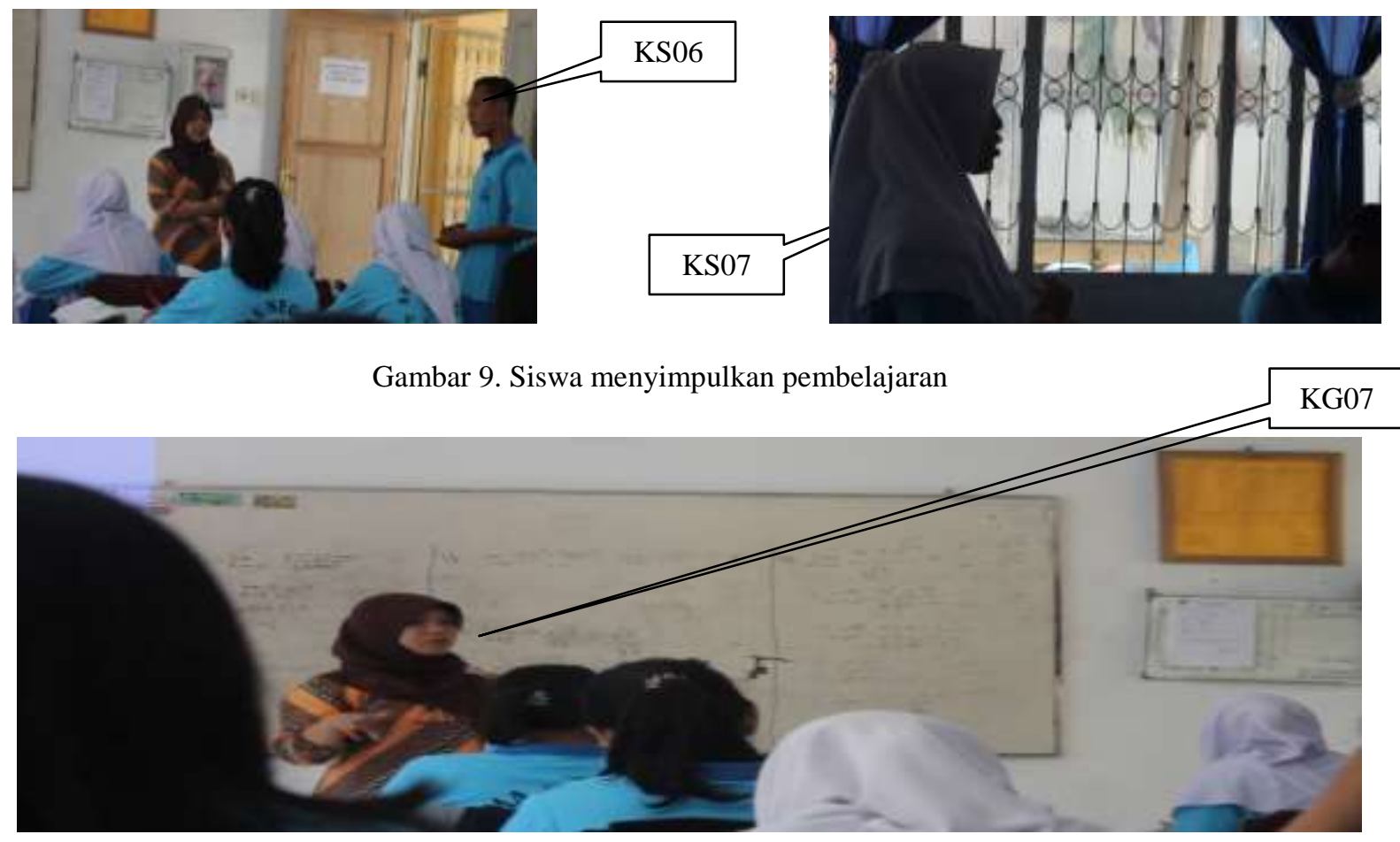

Gambar 10. Guru mengoreksi hasil simpulan siswa

Peneliti melakukan wawancara dengan guru untuk memperoleh informasi lebih lanjut, sebagaimana transkip berikut:

WR 01 P : Dalam melaksanakan pembalajaran, ada kegiatan pendahuluan, inti dan penutup. Bagaimana cara ibu melakukan kegiatan tersebut? 
WR 02G : Untuk kegiatan pendahuluan, ibu mempersiapkan siswa untuk belajar terlebih dahulu, dengan cara bertanya kepada mereka "sudah siap" ketika mereka bilang sudah siap, ibu memperhatikannya lagi. Nah, ketika semuanya sudah siap ibu membuka pembelajaran dengan mengucapkan salam. Kemudian, ibu mengecek kehadiran mereka satu persatu dan menyampaikan materi yang akan dipelajari melalui power point.

WR 03 P : Setelah itu bu?

WR $04 \mathrm{G}$ : Setelah itu menyampaikan kompetensi dasar yang akan dicapai dan memberikan motivasi siswa terlebih dahulu dengan cara memberikan pertanyaan kepada siswa. Nah setelah itu ibu masuk dikegiatan inti.

WR 05 P : Apa saja yang ibu lakukan di kegiatan inti?

WR 06 G : Dalam kegiatan ini, ibu menjelaskan materi kepada siswa dengan menggunakan power point, setelah itu ibu bertanya kepada mereka "sudah paham" ketika mereka bilang sudah paham ibu coba memberikan contoh soal kepada mereka dan meminta mereka mengerjakan di papan tulis. Setelah selesai, ibu mengkoreksi jawaban mereka.

WR $07 \mathrm{P}$ : Setelah itu?

WR 08 G: Karena mareka sudah paham, ibu kemudian memberikan soal kepada mereka, tetapi terlebih dahulu ibu membagi mereka kedalam beberapa kelompok, ibu membagi berdasarkan karakteristik mereka yaitu ada yang tinggi, sedang, dan rendah. Setelah kelompoknya terbentuk, ibu membagikan LKS kepada masingmasing kelompok dan meminta mereka mengerjakan soal yang ada pada LKS dalam waktu yang ibu tentukan.

WR 09 P : Pada saat mereka mengerjakan soal, apa yang ibu lakukan?

WR 10 G: Ibu memantau mereka dengan berjalan ke tiap-tiap kelompok, dan ketika ada yang merasa kesulitan ibu membantu mereka dengan cara mengajarkan hal yang mereka anggap sulit.

WR $11 \mathrm{P}$ : Setelah itu, Bu?

WR 12 G: Setelah waktunya sudah selesai, ibu meminta kepada tiap-tiap kelompok untuk memaparkan jawaban mereka di depan, ketika mereka selesai, ibu mengamati jawaban mereka dan mengoreksinya, dan ketika masih ada kesalahan atau masih ada cara yang lain dalam menjawab soal tersebut, ibu meminta temantemannya yang lain untuk menyelesaikannya. Jika semuanya sudah benar ibu memberikan tepuk tangan kepada mereka semua. Kemudian, ibu meminta mereka mencatat jawaban-jawaban temannya yang ada di papan tulis. Setelah itu, ibu meminta mereka kembali ke tempatnya masing-masing.

WR $13 \mathrm{P}$ : Kemudian apa yang ibu lakukan di kegiatan penutup?

WR 14 G: Pada akhir pertemuan, ibu membimbing siswa untuk memberikan kesimpulan, biasanya ibu memberikan kesempatan terlebih dahulu kepada siswa untuk menyimpulkan, kemudian ibu menambahkanya. Setelah itu, ibu memberikan arahan nasihat kepada siswa agar tetap semangat belajar dan memberikan PR kepada mereka. Terakhir ibu menutup pembelajaran dengan mengucapkan salam.

\section{PEMBAHASAN}

Pembuatan perencanaan pelaksanaan pembelajaran (RPP) yang dimiliki oleh guru tersebut sudah sesuai dengan pedoman pembuatan RPP yang di dalamnya terdapat 
komponen-komponen dan sistematika RPP yang meliputi identitas sekolah, identitas mata pelajaran, kelas/semester, materi pokok, alokasi waktu, KD, indikator, tujuan pembelajaran, materi, model atau metode, kegiatan pembelajaran, media/sumber belajar, dan penilaian. Hal ini sesuai dengan Peraturan Menteri Pendidikan dan Kebudayaan Nomor 22 Tahun 2016 tentang standar Proses Pendidikan Dasar dan Menengah dan Permendikbud Nomor 103 Tahun 2014 tentang Pembelajaran pada Pendidikan Dasar dan Menengah bahwa komponen RPP yaitu terdiri identitas sekolah, identitas mata pelajaran, kelas/semester, materi pokok, alokasi waktu, KD, indikator, tujuan pembelajaran, metode pembelajaran, kegiatan pembelajaran, media, sumber belajar, dan penilaian hasil belajar.

Setelah merencanakan pembelajaran maka tugas guru selanjutnya yaitu melaksanakan pembelajaran. Pelaksanaan pembelajaran adalah proses yang diatur dengan tahapan-tahapan tertentu agar pelaksanaannya mencapai hasil yang diharapkan. Adapun tahapan-tahapan pembelajaran menurut Majid (2005:104) meliputi kegiatan awal, kegiatan inti, dan kegiatan penutup. Pada kegiatan pendahuluan, guru terlebih dahulu mempersiapkan siswa untuk belajar dan membuka pembelajaran dengan mengucapkan salam, hal ini sesuai yang dikemukakan oleh Suparlan (2008:150) bahwa dalam membuka suatu pembelajaran, langkah pertama yang dilakukan yaitu mengucapkan salam, pendidik dapat memberikan salam kepada siswanya demikian juga siswa dibiasakan memberi salam kepada gurunya. Tujuannya yaitu untuk menumbuhkan sikap religius siswa. Kemudian mengecek kehadiran siswa. Setelah itu guru memberikan motivasi dan apersepsi kepada siswa dengan memberikan pertanyaan atau soal yang berkaitan dengan pembelajaran sebelumnya, tujuannya untuk mengukur dan mengetahui sejauh mana materi yang akan dipelajari sudah dikuasi oleh siswa. Hal ini sesuai dengan yang dikemukakan oleh Ahmad (2004:27) bahwa apersepsi dapat disajikan melalui pertanyaan untuk mengetahui apakah siswa masih ingat/lupa, sudah dikuasai/belum materi yang dipelajari oleh siswa pada pembelajaran sebelumnya, hasilnya untuk menjadi titik tolak dalam memulai pengajaran yang baru. Kemudian guru menyampaikan materi yang akan dipelajari tujuannya agar siswa tahu materi yang akan dipelajari. Selanjutnya, guru menyampaikan kompetensi dasar yang akan dicapai. Tujuannya menyampaikan kompetensi dasar agar siswa menyadari dan mengetahui apa yang dipelajari untuk mencapai kompetensi tersebut.

Guru menjelaskan materi kepada siswa saat kegiatan inti dengan bertanya terlebih dahulu ke siswa, kemudian melanjutkan penjelasannya. Guru menjelaskan materi ke siswa menggunakan power point kemudian memberikan contoh soal dan meminta salah satu siswa untuk mengerjakan contoh soal tersebut di papan tulis. Setelah selesai, guru memberikan soal kepada siswa dengan tujuan untuk mengevaluasi pemahaman siswa terhadap materi yang diberikan, seperti yang dikatakan oleh Masnur (2008:118) bahwa evaluasi dimaksudkan untuk mengetahui seberapa besar siswa mampu menerima atau memahami materi yang disampaikan oleh guru selama proses pembelajaran. Kemudian siswa mengejarkan soal secara berkelompok tujuannya agar siswa bisa menumbuhkan sikap kerja sama dan saling membantu jika ada temannya yang mengalami kesulitan. Hal ini sesuai dengan hal yang dikemukakan oleh Isjoni (2010: 85) bahwa untuk membentuk sikap kerja sama maka guru hendak membentuk diskusi kelompok agar dapat saling membantu antar sesama.

Guru memantau siswa saat siswa mengerjakan soal dan bertindak sebagai fasilitator jika ada siswa yang mengalami kesulitan, seperti yang dikatakan oleh Wina (2008:34) bahwa seorang guru harus bertindak sebagai fasilitator di kelas yang berperan memberikan pelayanan untuk memudahkan siswa, jika siswa mengalami kesulitan. Selanjutnya setelah selesai mengerjakan soal, guru tersebut meminta perwakilan siswa untuk memaparkan hasil 
jawabannya di papan tulis, setelah itu guru mengamati jawaban tersebut, ketika terjadi kesalahan maka guru mengoreksinya, dan meminta siswa untuk mencatat jawaban yang dipaparkan oleh temannya. Kemudian, guru memberikan reward kepada siswa yang sudah menjawab dengan tepuk tangan. Tujuannya agar menumbuhkan semangat dan minat siswa dalam belajar. Hal ini sesuai dengan yang dikemukakan oleh Hamalik (2009:184) bahwa reward memiliki tujuan untuk membangkitkan semangat dan minat siswa.

Kegiatan pada akhir pertemuan yaitu guru membimbing siswa untuk menyimpulkan hasil pembelajaran yang sudah dilaksanakan. Tujuannya agar memberikan penguatan terhadap hasil belajar siswa, kemudian guru memberikan tugas kepada siswa untuk dikerjakan di rumah. Pembelajaran ditutup dengan mengucapkan salam.

\section{KESIMPULAN}

Berdasarkan hasil analisis data penelitian, dapat disimpulkan bahwa kemampuan guru dalam merencanakan dan melaksanakan pembelajaran adalah sebagai berikut 1) perencanaan pelaksanaan pembelajaran sudah sesuai dengan pedoman pembuatan RPP yang dikeluarkan oleh Kementerian Pendidikan dan Kebudayaan tentang Pembelajaran pada Pendidikan Dasar dan Menengah yang di dalamnya terdapat komponen-komponen RPP yaitu identitas sekolah, identitas mata pelajaran, kelas/semester, materi pokok, alokasi waktu, KD, indikator, tujuan pembelajaran, metode, kegiatan pembelajaran, media, sumber belajar, dan penilaian hasil belajar. 2) Kegiatan pendahuluan, guru terlebih dahulu mempersiapkan siswa untuk belajar, membuka pembelajaran dengan mengucapkan salam, mengecek kehadiran siswa, menyampaikan materi, memberikan apersepsi dan motivasi kepada siswa dengan bertanya, dan memberikan kompetensi dasar yang akan dicapai oleh siswa. 3) Kegiatan inti, guru menjelaskan materi kepada siswa dengan cara menjelaskanya menggunakan power point dan menulis di papan tulis dengan memberikan contoh soal. Selanjutnya, guru memberikan siswa beberapa soal untuk dikerjakan secara berkelompok. Setelah selesai, siswa memaparkan jawaban mereka di papan tulis dan dikoreksi oleh guru. Guru memberikan penghargaan kepada siswa yang sudah menjawab soal dan meminta siswa yang lain untuk mencatatnya, setelah semuanya selesai guru meminta mereka kembali ke tempat semula. 4) Kegiatan penutup, pada akhir pertemuan guru membimbing siswa untuk menyimpulkan hasil pembelajaran yang sudah dilaksanakan. Tujuannya agar memberikan penguatan terhadap hasil belajar siswa, dan terakhir yaitu guru memberikan tugas kepada siswa untuk dikerjakan di rumah. Kemudian, pembelajaran ditutup dengan mengucapkan salam.

\section{SARAN}

Berdasarkan hasil penelitian yang dilakukan, peneliti mengharapkan agar guru matematika yang mengajar di SMA Negeri 3 Palu lebih meningkatkan dan terus mempertahankan kemampuan dalam merencanakan dan melaksanakan pembelajaran sehingga proses belajar mengajar di kelas bisa tercapai dengan sangat baik. Selain itu, guru dalam mengajarkan matematika harus memperhatikan kemampuan matematika yang dimiliki siswanya, agar guru dapat merancang kegiatan pembelajaran yang sesuai dengan kemampuan yang dimiliki oleh siswa, sehingga siswa dapat memahami materi yang diajarkan dengan baik. 
Herdawati, Sutji Rochaminah, dan Baharuddin Paloloang, Kemampuan Guru ... 71

\section{DAFTAR PUSTAKA}

Agung, Leo. (2013). Perencanaan pembelajaran. Yogyakarta: Ombak

Ahmad, R. (2004). Pengelolaan Pengajaran. Jakarta: PT. Rineka Cipta

Hamalik, O. (2009). Pendidikan Guru Berdasarkan Pendekatan Kompetensi. Jakarta: PT. Bumi Aksara

Isjoni, H. (2010). Cooperative Learning. Bandung: Alfabeta

Majid, A. (2005). Perencanaan Pembelajaran: Mengembangkan Standar Kompetensi Guru. Bandung: PT Remaja Rosdakarya

Marno. (2009). Strategi dan metode pengajaran Menciptakan Keterampilan Mengajar yang Efektif dan Edukatif. Jakarta: Ar-Ruzz Media

Masnur, M. (2008). Pembelajaran Kontekstual. Semarang: Media Group

Miles, M.B. dan Huberman, A.M (1992). Ananlisis Data Kualitatif. [Online], Tersedia: http://dunia-penelitian.blogspot.com/2011/11/penelitian-kualitatif-dan-teknik.html. (29 Mei 2016).

Nurdin, M. (2010). Kiat menjadi guru profesional. Jakarta: Ar- Ruzz Media

Suparlan. (2008). Pembelajaran Aktif, Kreatif, dan Menyenangkan. Bandung: PT Genesindo

Wina, S. (2008). Strategi Pembelajaran: Berorientasi Standar Proses Pendidikan. Jakarta: Kencana Prenada 